\title{
Catalogue of Polar Bear (Ursus maritimus) Maternal Den Locations in the Beaufort and Chukchi Seas and Nearby Areas, 1910-2018
}

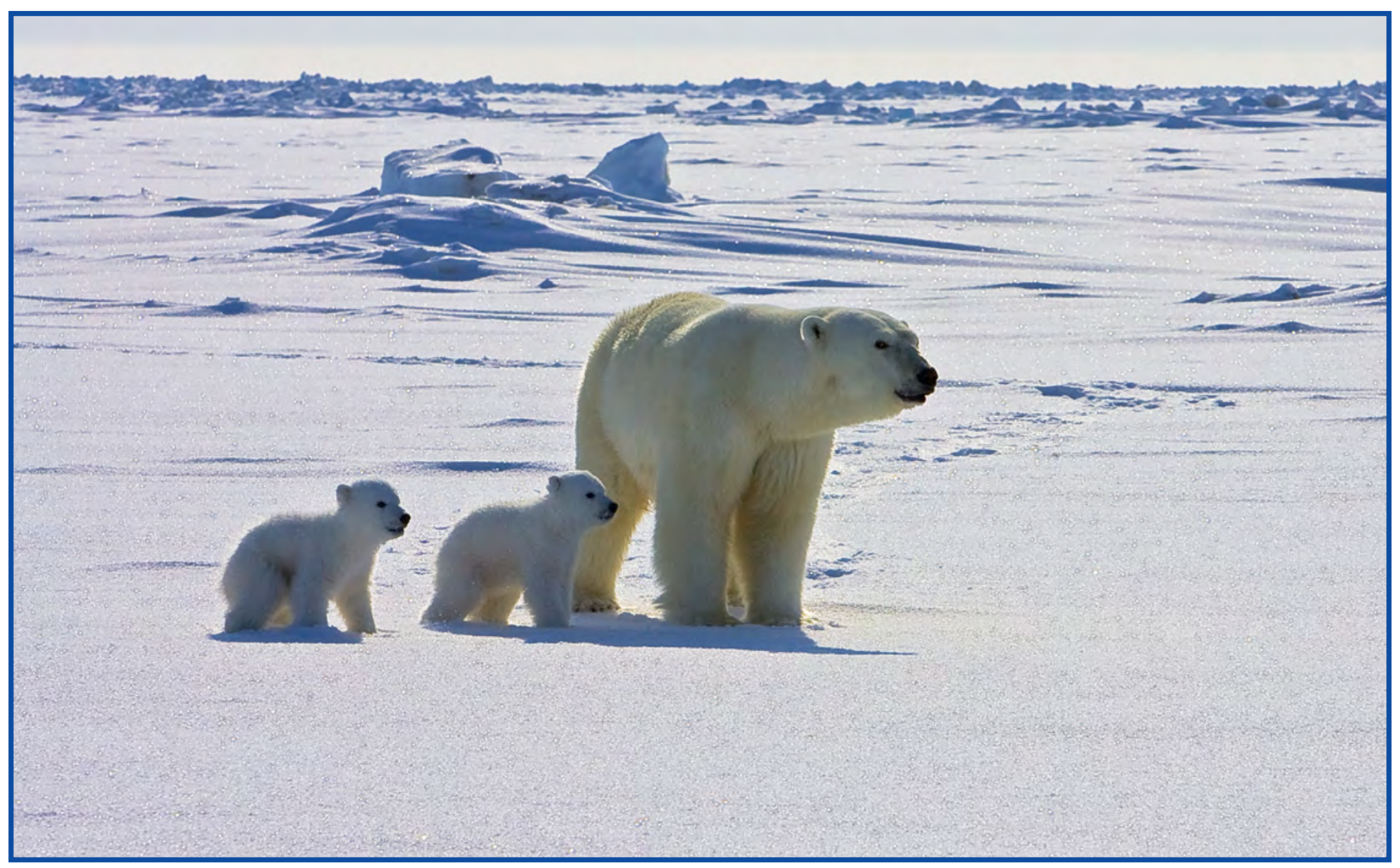

Data Series 1121

Supersedes USGS Data Series 568 
Cover: Adult female polar bear and her two cubs traveling across the sea ice of the Arctic Ocean north of the Alaska coast, April 2008. Photograph by Mike Lockhart, U.S. Geological Survey. 


\section{Catalogue of Polar Bear (Ursus maritimus) Maternal Den Locations in the Beaufort and Chukchi Seas and Nearby Areas, 1910-2018}

By George M. Durner, Steven C. Amstrup, Todd C. Atwood, David C. Douglas, Anthony S. Fischbach, Jay W. Olson, Karyn D. Rode, and Ryan R. Wilson

Data Series 1121

Supersedes USGS Data Series 568 


\title{
U.S. Department of the Interior DAVID BERNHARDT, Secretary
}

\author{
U.S. Geological Survey \\ James F. Reilly II, Director
}

\author{
U.S. Geological Survey, Reston, Virginia: 2020 \\ Supersedes USGS Data Series 568
}

\begin{abstract}
For more information on the USGS - the Federal source for science about the Earth, its natural and living resources, natural hazards, and the environment-visit https://www.usgs.gov or call 1-888-ASK-USGS.

For an overview of USGS information products, including maps, imagery, and publications, visit https://store.usgs.gov.
\end{abstract}

Any use of trade, firm, or product names is for descriptive purposes only and does not imply endorsement by the U.S. Government.

Although this information product, for the most part, is in the public domain, it also may contain copyrighted materials as noted in the text. Permission to reproduce copyrighted items must be secured from the copyright owner.

Suggested citation:

Durner, G.M., Amstrup, S.C., Atwood, T.C., Douglas, D.C., Fischbach, A.S., Olson, J.W., Rode, K.D., and Wilson, R.R., 2020, Catalogue of polar bear (Ursus maritimus) maternal den locations in the Beaufort and Chukchi Seas and nearby areas, 1910-2018: U.S. Geological Survey Data Series 1121, 12 p., including appendixes,

https://doi.org/10.3133/ds1121. [Supersedes USGS Data Series 568.]

Associated data for this publication:

Durner, G.M., 2010, Catalogue of polar bear (Ursus maritimus) maternal den locations in the Beaufort and Chukchi seas and nearby areas, 1910-2018 (ver. 2.0, January 2020): U.S. Geological Survey data release, https://doi. org/10.5066/P9RPHH50.

ISSN 2327-638X (online) 


\section{Contents}

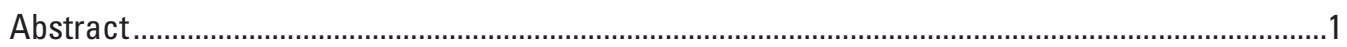

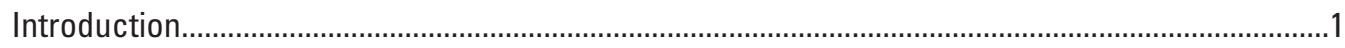

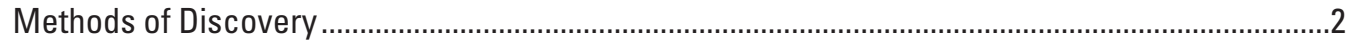

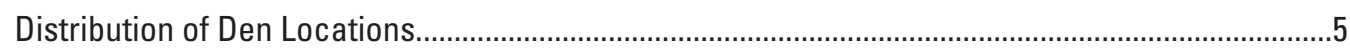

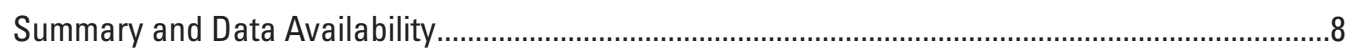

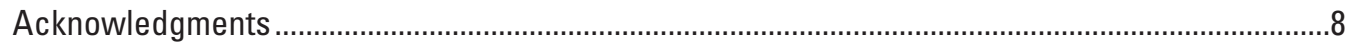

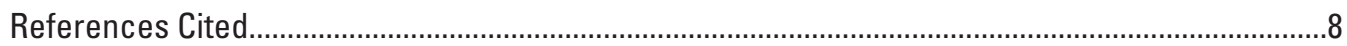

Appendix 1. Determination of Spatial Uncertainty .......................................................................

Appendix 2. Dens Appearing in Durner and Others (2010) That Are Excluded From This Data Series and Its Associated Data Release .................................................................11

Appendix 3. Definition of Categorical Data Codes ........................................................................12

\section{Figures}

1. Photograph showing female polar bear emerging from her maternal den adjacent to a coastal bank on Foggy Island, near Prudhoe Bay, Alaska, April 2009 ........2

2. Maps showing distribution of polar bear maternal dens discovered through satellite telemetry, very high frequency (VHF) telemetry, reported by others, and during polar bear survey operations on sea ice and nearshore areas, for the Beaufort and Chukchi Seas and neighboring regions,1910-2018...

3. Map showing distribution of polar bear maternal dens discovered through Forward-Looking Infrared (FLIR) sensor surveys of terrestrial denning habitat in the Prudhoe Bay region of the Beaufort Sea coast, 1999-2017.

4. Maps showing distribution of polar bear maternal dens discovered by very high frequency (VHF) telemetry during 1981-91 when most data were collected through systematic surveys, and after 1991 when VHF telemetry missions only occurred near shore in the Beaufort Sea. 


\section{Conversion Factors}

U.S. customary units to International System of Units

\begin{tabular}{|c|c|c|}
\hline Multiply & By & To obtain \\
\hline \multicolumn{3}{|c|}{ Length } \\
\hline mile, nautical (nmi) & 1.852 & kilometer $(\mathrm{km})$ \\
\hline \multicolumn{3}{|c|}{ International System of Units to U.S. customary units } \\
\hline Multiply & By & To obtain \\
\hline \multicolumn{3}{|c|}{ Length } \\
\hline meter $(\mathrm{m})$ & 3.281 & foot $(\mathrm{ft})$ \\
\hline kilometer $(\mathrm{km})$ & 0.6214 & mile (mi) \\
\hline
\end{tabular}

\section{Datums}

Field observations made prior to 1995 were recorded in North American Datum of 1927 and post-projected to the World Geodetic System 1984 (WGS84). All satellite-tag locations, and field observations made after 1994, were recorded in WGS84. 


\title{
Catalogue of Polar Bear (Ursus maritimus) Maternal Den Locations in the Beaufort and Chukchi Seas and Nearby Areas, 1910-2018
}

\author{
By George M. Durner ${ }^{1}$, Steven C. Amstrup², Todd C. Atwood ${ }^{1}$, David C. Douglas ${ }^{1}$, Anthony S. Fischbach ${ }^{1}$, Jay \\ W. Olson ${ }^{3}$, Karyn D. Rode', and Ryan R. Wilson ${ }^{4}$
}

\section{Abstract}

This report presents data on the approximate locations and methods of discovery of 530 polar bear (Ursus maritimus) maternal dens observed in the Beaufort and Chukchi Seas and neighboring areas from 1910 to 2018, and archived partly by the U.S. Geological Survey, Alaska Science Center, and partly by the U.S. Fish and Wildlife Service, Marine Mammals Management, in Anchorage, Alaska. A description of data collection methods and their associated biases, primary data collection time periods, and estimated position uncertainty are provided. Polar bears in the Beaufort and Chukchi Seas den on sea ice and land. Standardized very high frequency (VHF) aircraft surveys and satellite radio telemetry data provide a general understanding of where polar bears have denned in this region over the past 3 decades. Den observations made during other research activities and anecdotal reports from other government agencies, coastal residents, and industry personnel also are reported. These data on past polar bear maternal den locations are provided to inform decision making by natural resource agencies and for public use.

\section{Introduction}

Polar bears (Ursus maritimus) require dens of snow and ice that remain undisturbed throughout den tenure for the successful parturition and early development of neonates. Suitable denning habitat generally occurs on the leeward side of terrestrial banks and bluffs, or sea ice pressure ridges, where drifting snow can accumulate (Durner and others, 2003; fig. 1). A large proportion of polar bear maternal dens observed in the Beaufort and Chukchi seas have occurred on drifting pack ice rather than land, making bears in this region unique relative to those in other parts of their circumpolar range (Amstrup and Gardner, 1994; Fischbach and others, 2007; Rode and others, 2018). In northern Alaska and adjacent areas in Canada, denning habitat and the timing of maternal denning may overlap with industrial activities, presenting a potential for negative interactions between polar bears and humans. Given this rigid life history requirement and an increasing human presence in the Arctic, the distribution of maternal denning is considered important information for management decisions that have implications in the conservation of polar bears.

This report and the associated data release (Durner, 2020) provide potential users with point locations of polar bear maternal dens observed in the marine and terrestrial habitats of the Beaufort and Chukchi Seas, 1910-2018. Its primary purpose is to inform natural resource agencies in their efforts to minimize interactions between human activities and polar bear maternal dens. The den data are a mix of anecdotal observations, reports from other governmental agencies, nonstandardized and standardized surveys, and satellite telemetry records. The polar bear maternal den records presented here supersede an earlier version of these data (Durner and others, 2010).

\footnotetext{
${ }^{1}$ U.S. Geological Survey

${ }^{2}$ Polar Bears International

${ }^{3}$ U.S. Forest Service

${ }^{4}$ U.S. Fish and Wildlife Service
} 


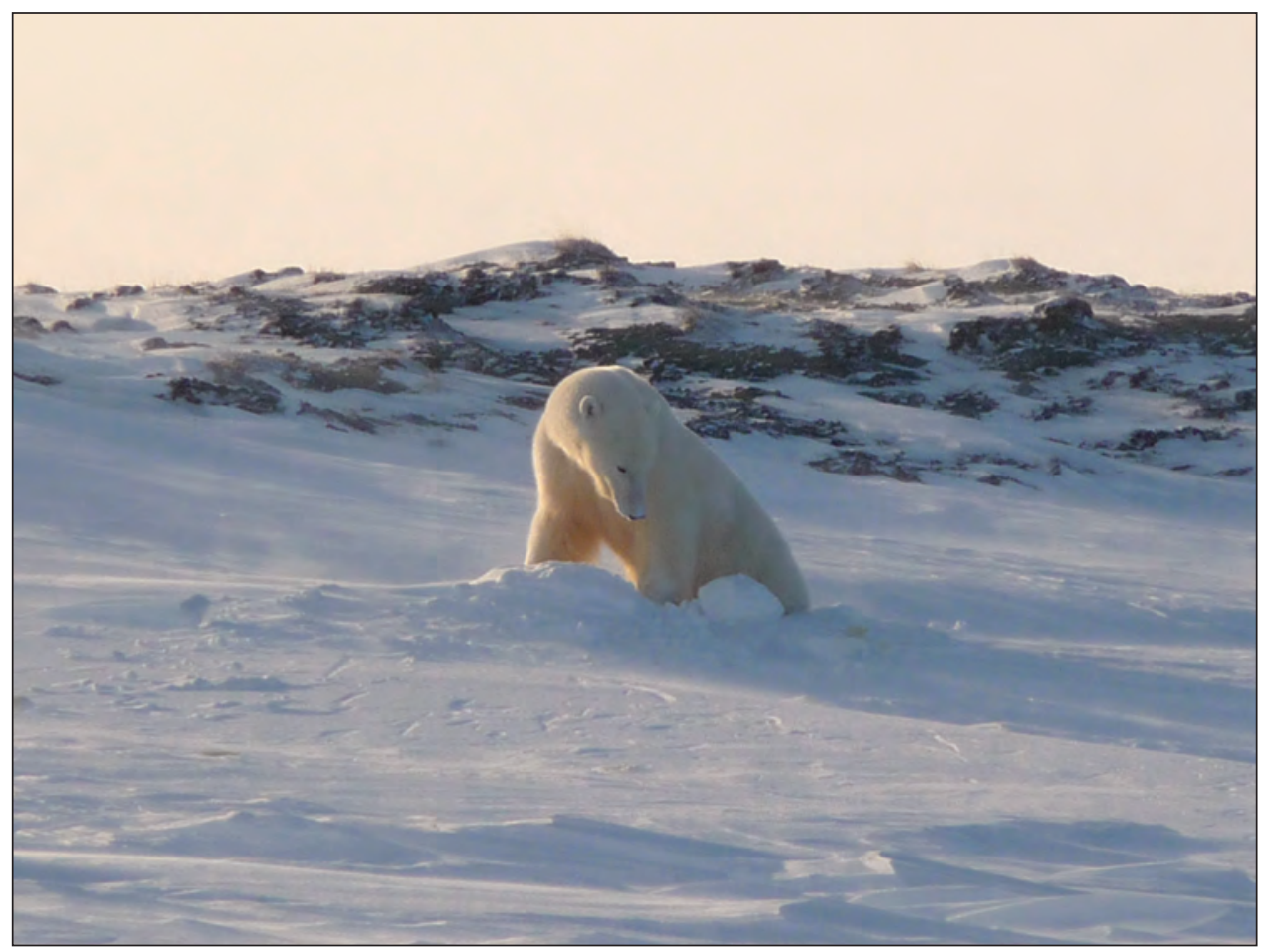

Figure 1. Female polar bear emerging from her maternal den adjacent to a coastal bank on Foggy Island, near Prudhoe Bay, Alaska, April 2009. Photograph by Rusty Robinson, Brigham Young University, Provo, Utah. Used with permission.

\section{Methods of Discovery}

Data in this report span more than a century of polar bear maternal den observations by residents and visitors to the Arctic, industry personnel, and natural resources agencies of Borough, State, and Federal governments. From 1965 to 1972, polar bear research and management was under the jurisdiction of the Alaska Department of Fish and Game (ADFG), including the recording of polar bear maternal dens (Lentfer and Hensel, 1980). Following passage of the Marine Mammal Protection Act in 1972, all polar bear research and management were transferred to separate divisions of the U.S. Fish and Wildlife Service (FWS). In 1993, most Department of the Interior (DOI) biological research was moved into the National Biological Survey (under Secretarial Order 3173) and later renamed the National Biological Service (under Secretarial Order 3185). Another transfer of DOI research occurred in 1996 when the National Biological Service was moved into the U.S. Geological Survey (USGS) as the Biological Resources Division (Wagner, 1999). Because these different agencies housed a continuation of the same research program, they are collectively referred to as the USGS. In 2008 the FWS, Marine Mammals Management Office, assumed research efforts in the Alaska Chukchi Sea, including the capture and radio-tagging of adult female polar bears and the identification of maternal dens.
Prior to 1980, most data on polar bear maternal dens in the Beaufort and Chukchi Seas were observations collected through interviews of coastal residents, guides of polar bear hunters, and industry personnel (Lentfer and Hensel, 1980). Additional observations were made during autumn fixedwing aircraft surveys of nearshore habitats by the ADFG (during 1965, 1967, and 1971), the FWS (during 1973, 1974, and 1976), and by the FWS (during March and April 1973, 1974, and 1975; Lentfer and Hensel, 1980). Opportunistic observations of maternal dens were recorded during spring (March and April) mark-recapture research (Lentfer, 1975; Lentfer and others, 1980) in northwestern and northern Alaska by the ADFG (during 1967-72) and the FWS (during 1974-76).

Federal research of polar bears expanded greatly beginning in 1980 with an intensification of mark-recapture and animal-tracking efforts. From 1980 through 1994, capturemark-recapture efforts focused on estimating the population size of polar bears in the southern Beaufort Sea (Amstrup and others, 1986, 2001). These efforts involved 4-6 weeks of fieldwork each spring and 4-5 weeks during some autumns. In 1981, radio tracking began after the development of very high frequency (VHF) radio transmitter collars that were suitable for deployment on adult female polar bears. In 1985, the USGS began deployment of satellite-linked radio transmitters (Platform Transmitter Terminal, or PTT) on polar bears in the Beaufort and Chukchi Seas (Fancy and others, 1988). 
PTT signals received by satellites were processed by the $\operatorname{Argos}^{\mathrm{TM}}$ system (Collecte Localisation Satellites, or CLS; Toulouse, France; http:/www.argos-system.org/), which then provided users with estimates of PTT location and sensor data (that is, activity and temperature of the transmitter). Beginning in 2004, most PTTs deployed by the USGS were equipped with Global Positioning System (GPS) receivers, the data of which were sent to satellites as a sensor string. In 2014, the USGS began deployment of transmitters that relayed GPSbased location and sensor data through the Iridium ${ }^{\circledR}$ Satellite Communications system (Iridium Satellite Communications, McLean, Virginia). Hereinafter, we refer to both PTTs and Iridium radios as satellite-linked tags.

Several methods were used to collect observations on polar bear maternal dens. Standardized VHF surveys in the eastern Chukchi Sea, Beaufort Sea, and northwestern Canada were done by aircraft four times each winter during 1983-87, and twice each winter during 1988-91 (Amstrup and Gardner, 1994) to locate polar bear maternal dens. Following 1985, location and sensor data from satellite-linked tags deployed on female polar bears in the Beaufort and Chukchi Seas enabled the remote identification of maternal dens (Amstrup and Gardner, 1994; Fischbach and others, 2007; Garner and others, 1990; Olson and others, 2017; Rode and others, 2018). Additionally, the USGS recorded observations reported by Borough, State, and Federal agencies, as well as observations by local residents, industry personnel, and other groups visiting Arctic coastal regions in Alaska. Most reported observations were provided to the USGS by the FWS, Marine Mammals Management. Maternal dens also were observed and recorded by USGS personnel incidental to standard searches for polar bears during nearshore capture-recapture and radio-collaring efforts. The development of VHF radio tags, combined with standardized high-altitude radio-tracking surveys and the deployment of satellite-linked tags, provided data of maternal dens that were largely free from geographic biases inherent in other types of observations. Data resulting from these tracking methods allowed a better understanding of the distribution and timing of polar bear maternal denning.

Following a short hiatus in data collection that began in 1995, the USGS resumed polar bear field research in autumn 1997 in the Beaufort Sea (Regehr and others, 2006; Bromaghin and others, 2015). Autumn field research ceased after 2001 because of delayed autumn ice formation that had become common and prevented reliable autumn captures. From 1997 to 2016, the USGS continued to deploy satellitelinked and some VHF radio tags. Beginning in 2008, the FWS deployed satellite-linked tags on adult female polar bears in the eastern Chukchi Sea during spring field seasons. Since the publication by Amstrup and Gardner (1994), assessments of the distribution of maternal denning have been done mostly with sensor and location data derived from satellite-linked tags (Fischbach and others, 2007; Olson and others, 2017; Rode and others, 2018). However, additional data were collected through restricted VHF telemetry surveys over the nearshore Alaska Beaufort Sea; experimental surveys with
Forward-Looking Infrared (FLIR; Amstrup and others, 2004) over likely polar bear denning habitat (Durner and others, 2003); and reports from local residents, industry personnel, and visitors to northern Alaska.

The FWS-Marine Mammals Management and the Alaska Department of Fish and Game provided additional den records for 2006-18. Maternal dens were identified in polar bear denning habitat (Durner and others, 2003) on barrier islands and coastlines near the Prudhoe Bay oilfield (that is, from $146^{\circ}$ $40^{\prime}$ to $151^{\circ} 00^{\prime}$ west longitude) through surveys with airborne FLIR, handheld infrared sensors, and trained scent dogs, and by industry reports. Confirmation of maternal dens was done following the methods described in Shideler (2014).

Because of the diversity of data sources and the substrate choice of polar bears (floating and mobile pack ice, immobile sea ice attached to land [that is, fast ice], or land), the spatial resolution of the den locations reported here varies. Most reported den observations were recorded to the nearest minute of latitude and longitude because they were estimated from a hunter's memory of where a den was observed many years prior. Dens observed during aircraft VHF missions, or by USGS field crews conducting polar bear captures prior to 1998, also were reported to the nearest minute of latitude and longitude. Likewise, den positions estimated from topographical maps were recorded to the nearest minute of latitude and longitude, and included the inherent spatial uncertainty associated with placement of a penciled dot on a physical map by the observer. Hence, for all den records whose positions were reported or were derived from aircraft or maps prior to regular use of GPS, we imposed a horizontal uncertainty of plus or minus 926 meters (m) (that is, one-half of 1 minute of latitude, or equivalently, one-half of 1 nautical mile) on the location.

Beginning in 1995, the USGS made use of military-grade GPS receivers to determine den locations during on-ground visits (appendix 1). Following 1998, all conventional, FLIR, and VHF radio-tracking aircraft missions used onboard GPS to record flight paths, mark locations of polar bears, and determine the location of maternal dens. Additionally, most satellite-linked tags used from 2004 and onward also had onboard GPS receivers. Whether field or satellite-tag derived, all GPS latitudes and longitudes were recorded to at least $1 / 10,000$ th of a degree (that is, the nearest 0.006 minute of latitude and longitude) and were assumed to have a spatial error of less than or equal to $30 \mathrm{~m}$. Locations provided through the Argos system were based on Doppler shifts measured during satellite overpass and satellite orbitography using least-squares processing methods (Lopez and others, 2014) and reported to $1 / 1000$ th of a degree (that is, the nearest 0.06 minute of latitude and longitude). Because Argos location estimates sometimes are highly erroneous, we post-processed Argos data with the Douglas Argos-filter (Douglas and others, 2012), which evaluated spatial redundancy, movement rate, turning angle, and the Argos location class to identify improbable locations and to select between the reported primary and alternate locations generated by CLS. 
Final quality of Argos locations, with 1-sigma (about 68-percent) location error radius, ranged from 0.4 kilometers (km; highest quality) to $7.6 \mathrm{~km}$ (lowest quality) of the true PTT position (see table 2 in Douglas and others, 2012). Additional details on how spatial uncertainty was determined are provided in appendix 1 .

Because sea ice continually drifts (except for nearshore fast ice) and can transport dens more than $100 \mathrm{~km}$ while occupied (Amstrup and Gardner, 1994), sea ice den locations are reported from a single field observation or a single satellite-linked position (generally a GPS or the best Argos quality record closest to the date after den entrance) and do not indicate the location of the den during the entire winter. In contrast, dens on land or fast ice remain stationary during den tenure. For land and fast ice dens whose positions were determined by satellite-linked data, we selected the record with the best location quality during den tenure. In cases of ties among the highest-quality locations, we averaged their coordinates and report that average.

Follow-up visits to dens, either by low-level aircraft reconnaissance or on-ground measures by personnel, resulted in improved estimates of den locations and verification of den occupancy. For example, many dens discovered by satellite telemetry during early winter were surveyed with aerial VHF telemetry in late winter. In such cases, the VHF telemetry location would supersede the previous satellite telemetryderived location. Likewise, dens may have been visited on the ground following their discovery by satellite telemetry or VHF telemetry. Because ground visits resulted in the most accurate den location, those locations superseded all prior estimates. This process typically resulted in minor changes of the recorded den location as new data became available. The records provided in this report are the best estimate of a den location as of 2019.

We excluded seven newly discovered dens from this data release because it was not possible to determine their position because of consistently poor PTT signal quality during den tenure. An additional seven dens that were listed in Durner and others (2010) also have been excluded after our review of these records indicated either insufficient data to support assignment as a den, absence of location data during den tenure, or identification of a duplicate record (see appendix 2).

Field descriptors for each data record include (1) the record number (Record); (2) the USGS-assigned den identification number (DenID); (3) the year during which the cubs would have emerged from the den (Spring_year); (4) the data source (Data_source); (5) the method used to discover the den (Discovery_method); (6) the latitude in decimal degrees (Latitude); (7) the longitude in decimal degrees (Longitude);
(8) an indicator of confidence that the observation was truly a polar bear maternal den (Confirmation); (9) the substrate on which the den occurred (Substrate); (10) the method used to determine the position of the den (Position_method); and (11) an estimate of position error (Horizontal_error_m). Confirmed dens (that is, Confirmation $=\mathrm{C}$ ) were those verified by on-site visits by personnel and (or) subsequent observations of the adult with dependent young. Probable dens (that is, Confirmation $=\mathrm{P}$ ) were those with supporting information to indicate maternal denning (for example, temperature, activity, and signal quality of satellite telemetry data), but lacked a site visit or a subsequent observation of the adult with young. See appendix 3 for the definition of codes used in categorical fields.

Field observations made prior to 1995 were recorded in North American Datum of 1927 and post-projected to the World Geodetic System 1984 (WGS84). All satellitetag locations, and field observations made after 1994, were recorded in WGS84. The data provided here are maternal den locations, where "maternal den" represents a structure that was used by a pregnant polar bear to give birth to young and, should parturition be successful, continue to be used as shelter for developing neonates until late winter or early spring when the family group would depart the den. Whether a structure was a maternal den was determined by assessing the timing and duration of den tenure, and assessing temperature, activity, and signal quality from satellite-linked radio tags. In using these criteria, there could be dens reported here that were occupied by a female that was not pregnant. Messier and others (1994) reported that non-pregnant female polar bears in the Canadian Arctic Archipelago used snow dens as shelters for short periods during winter. We tried to avoid inclusion of non-maternal dens by either verifying that a female was unaccompanied by cubs during the spring and autumn prior to denning, was accompanied by first-year cubs after denning, or remained in a den for a duration typical of successful maternal dens (for example, Olson and others, 2017; Rode and other, 2018). Direct observations of females with dependent young, visual inspection of the den following departure of the family, and visual inspection of the ground following snowmelt were used to confirm maternal denning. We excluded (1) USGS records of temporary dens not used for parturition, (2) autumn exploratory dens that apparently were not used or thought to be abandoned by the bear prior to parturition, (3) FLIR hotspots that later showed no evidence of being a maternal den, and (4) erroneous or questionable reports from other parties. Because these other observations were excluded, there are gaps in consecutive DenID records (see Durner, 2020). 


\section{Distribution of Den Locations}

We report a total of 530 polar bear maternal den records documented between 1910 and 2018 (see Durner, 2020, for the tabular data and metadata associated with this data series). PTT data analyzed by Rode and others (2018) from polar bears in the Chukchi Sea were the primary contributor to the increase in dens discovered by satellite radio telemetry (Discovery_method $=$ SATELLITE) from 169 (Durner and others, 2010) to 266 . The data release associated with this data series (Durner, 2020) also includes (1) observations reported by other individuals or institutions (Discovery_method $=$ REPORT, $\mathrm{n}=79$ ), (2) observations from polar bear field research (Discovery_method $=$ CONVENTIONAL, $\mathrm{n}=54$ ), (3) dens encountered by FLIR surveys (Discovery_method $=$ FLIR, $\mathrm{n}=30$ ), and (4) dens located by VHF telemetry (Discovery_method $=$ VHF_RADIO, $\mathrm{n}=101$ ). All VHF telemetry records were collected from 1982 to 2009, all satellite records were collected from 1986 to 2015, and all FLIR records were collected from 1999 to 2017. CONVENTIONAL observations were made from 1969 to 2013. REPORT observations were made from 1910 to 2018.
The discovery method strongly influenced the observed distribution of den locations. Dens discovered by satellite tracking were distributed throughout the Beaufort and Chukchi Seas and northwestern Canada (fig. 2A), indicating the advantage of this method for minimizing observation bias. Dens discovered by VHF telemetry observations, however, were restricted to the eastern Chukchi Sea, Beaufort Sea, and northwestern Canada (fig. 2B), indicating the general logistical range of aircraft paths in collecting data over a large region (Amstrup and Gardner, 1994). Dens whose discovery method was reported (Discovery_method = REPORT;

fig. 2C), discovered during polar bear field research operations (Discovery_method $=$ CONVENTIONAL; fig. $2 D$ ) or discovered with Forward-Looking Infrared surveys for dens (Discovery_method=FLIR; fig. 3) occurred mostly nearshore and on land, indicating the logistical limitations of where observers in the field conducted their activities and the spatial focus of industry surveys. The distribution of dens discovered by VHF telemetry also was dependent on the time period during which the data were collected. Whereas VHF telemetry data collected from 1983 to 1991 were through systematic Beaufort Sea and eastern Chukchi Sea-wide surveys (Amstrup and Gardner, 1994), VHF telemetry missions after this period only surveyed nearshore regions (fig. 4). 
A. Satellite telemetry, $\mathbf{n}=\mathbf{2 6 6}$

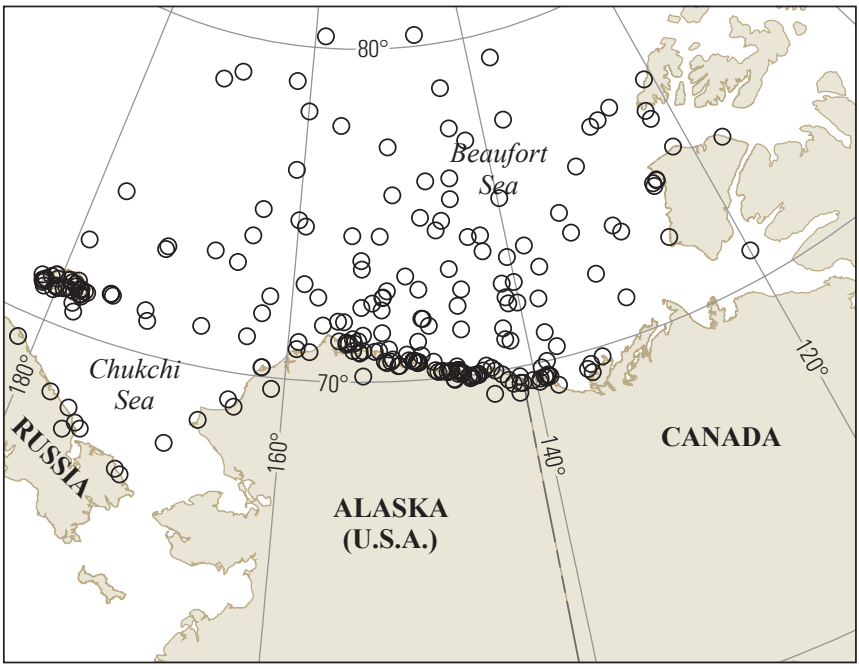

\section{Reported, $\mathbf{n}=79$}

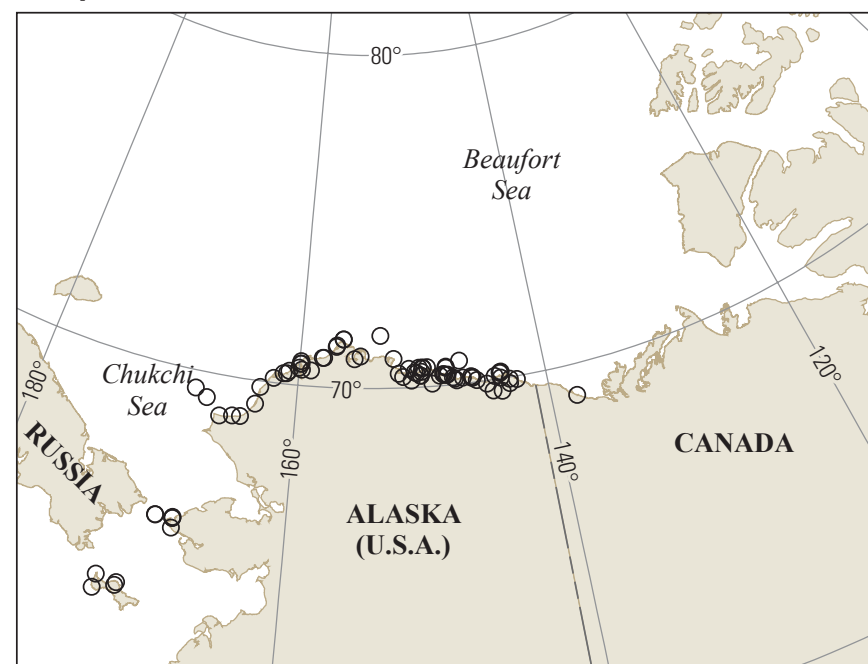

Base map from USGS and other digital data sources.

Coordinate reference system: Clarke 1866 Albers, $\mathrm{SP} 1=55^{\circ}$

$\mathrm{SP} 2=65^{\circ}, \mathrm{CM}=-154^{\circ}, \mathrm{LO}=50^{\circ}, \mathrm{FE}=5,000000, \mathrm{FN}=5,000,000$.

Horizontal datum is North American Datum of 1927.
B. VHF telemetry, $\mathrm{n}=101$

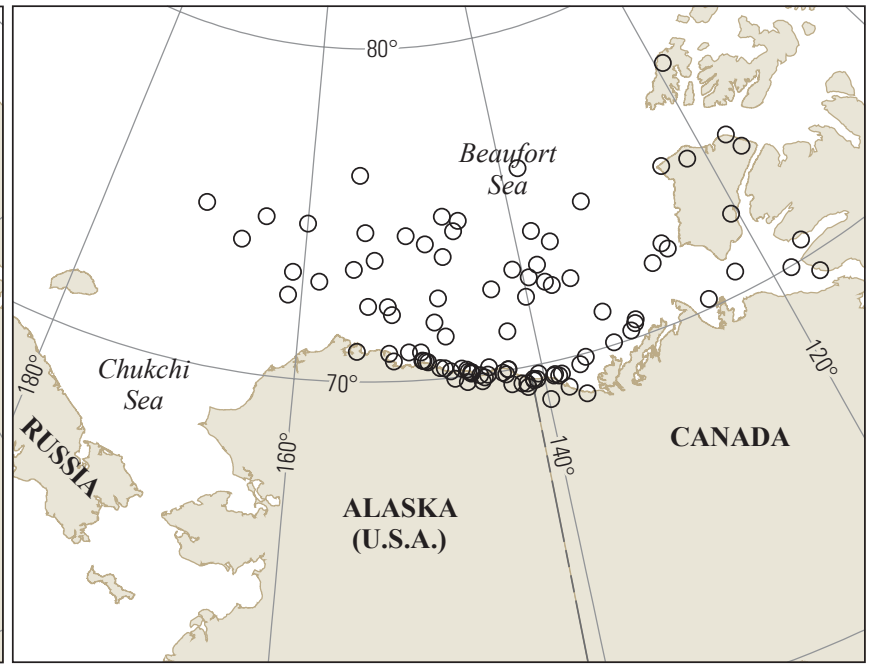

D. Conventional, $\mathrm{n}=54$

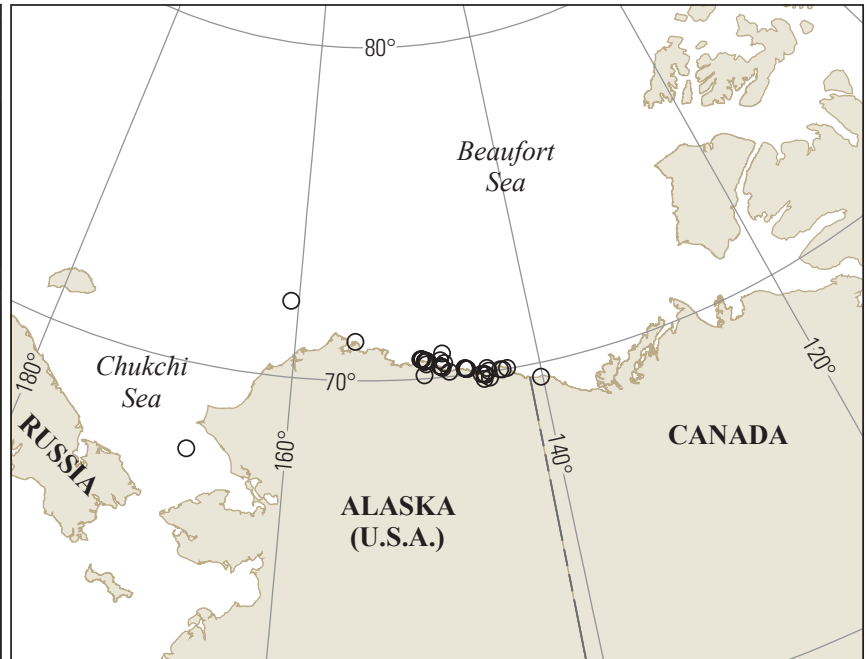

Figure 2. Distribution of polar bear maternal dens (hollow black circles) discovered through $(A)$ satellite telemetry, $(B)$ very high frequency (VHF) telemetry, $(C)$ reported by others, and $(D)$ during polar bear survey operations on sea ice and nearshore areas, for the Beaufort and Chukchi Seas and neighboring regions, 1910-2018. 
FLIR, $\mathbf{n}=\mathbf{3 0}$

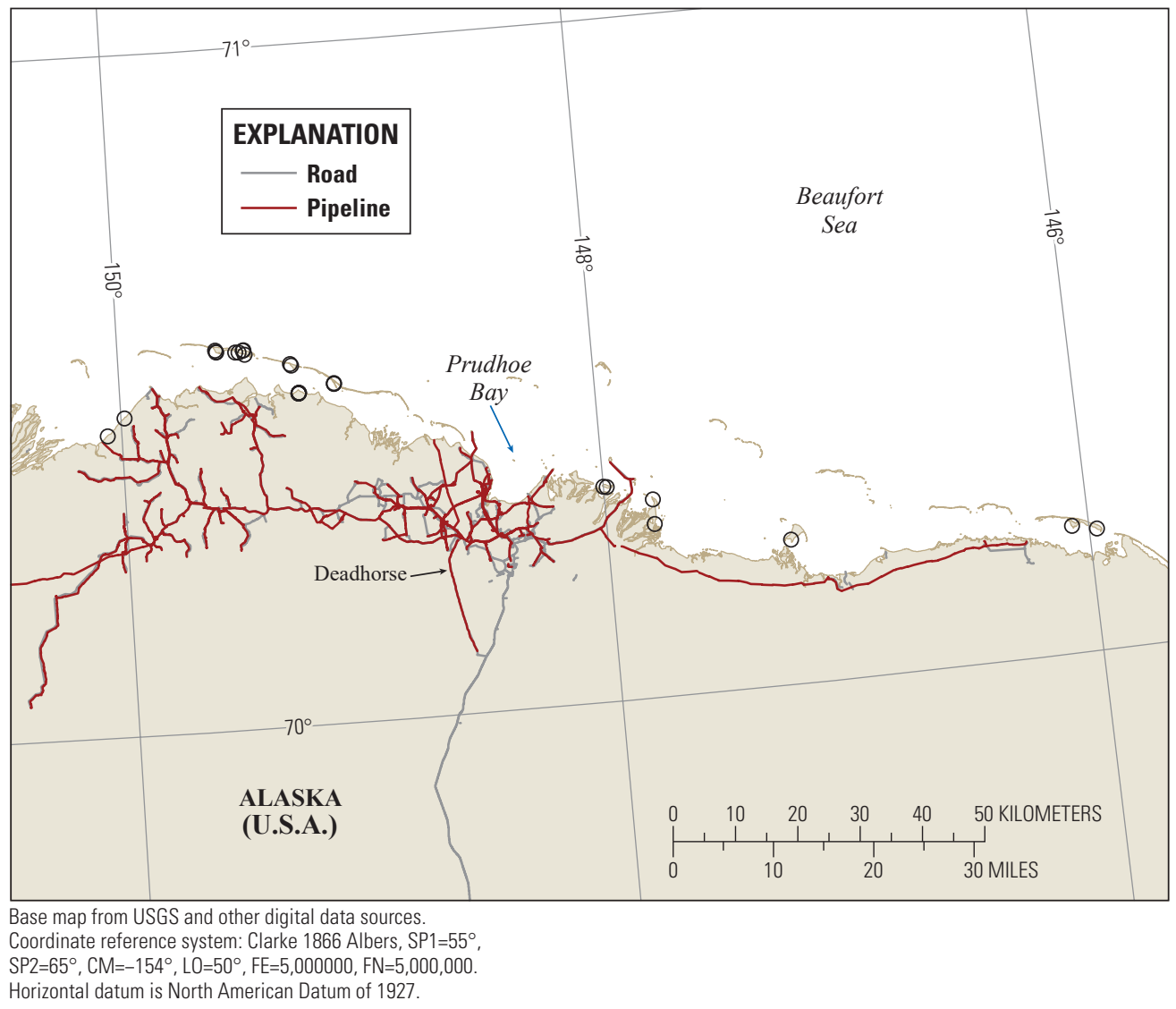

Figure 3. Distribution of polar bear maternal dens (hollow black circles) discovered through ForwardLooking Infrared (FLIR) sensor surveys of terrestrial denning habitat in the Prudhoe Bay region of the Beaufort Sea coast, 1999-2017.

A. VHF telemetry to $1991, \mathrm{n}=72$

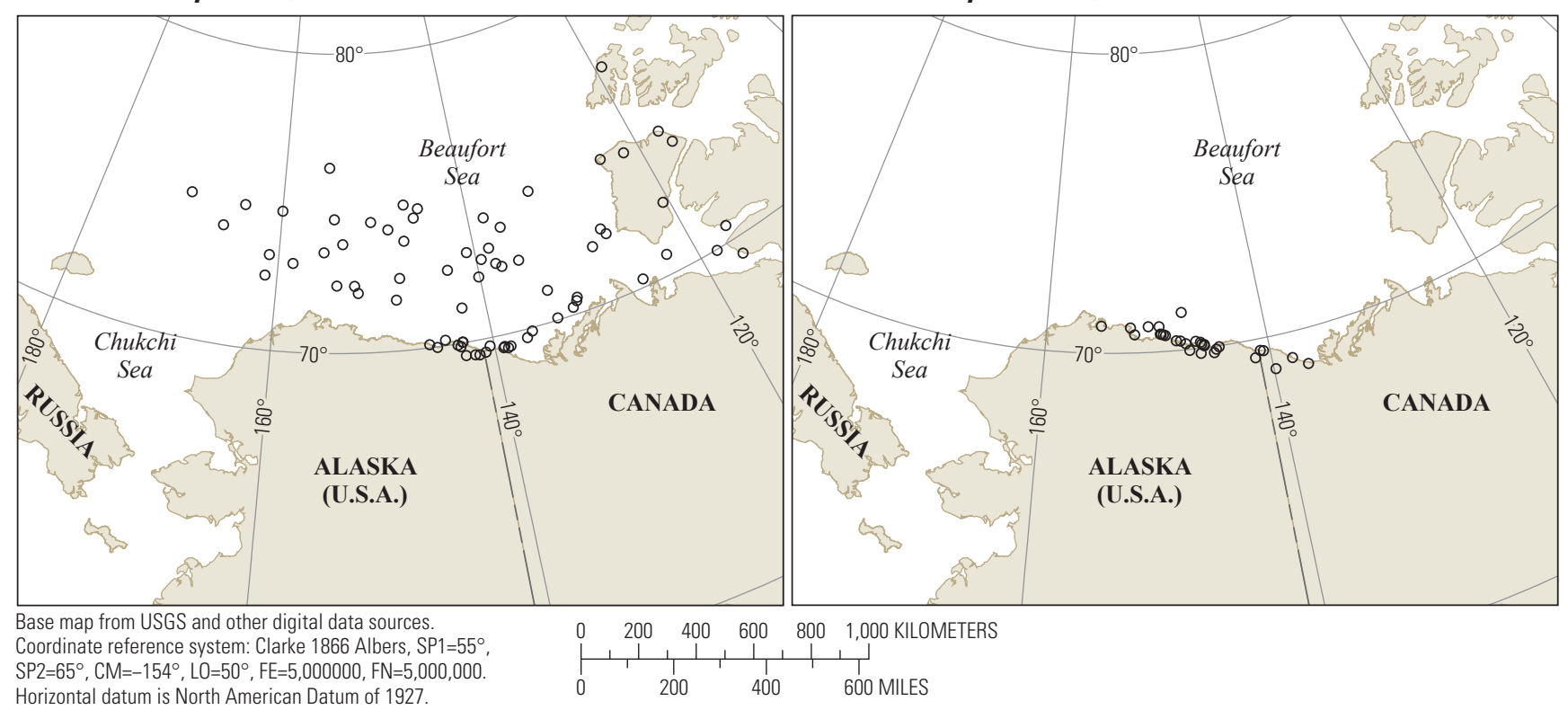

Figure 4. Distribution of polar bear maternal dens (hollow black circles) discovered by very high frequency (VHF) telemetry $(A)$ during 1981-91 when most data were collected through systematic surveys, and (B) after 1991 when VHF telemetry missions only occurred near shore in the Beaufort Sea. 


\section{Summary and Data Availability}

Records of maternal den locations in the Beaufort and Chukchi Seas and neighboring regions maintained by the U.S. Geological Survey, Alaska Science Center, are made available to resource managers and the public. Users are advised that observations of maternal dens, along with the spatial uncertainty and spatial bias of den locations, are dependent on the method of data collection; thus, certain methods will provide a better representation of den distribution than others.

\section{Acknowledgments}

The authors recognize the contributions of Gerald W. Garner (U.S. Geological Survey [USGS]) who deployed satellite collars on female polar bears in the Chukchi Sea from 1987 to 1994. We acknowledge Stanislav E. Belikov (All-Russian Research Institute for Nature Conservation and Reserves) and Mikial S. Stishov (Wrangel Island State Nature Reserve), whose collaboration with Gerald W. Garner made possible the deployment of satellite collars on polar bears along Russia's Chukotka Peninsula and Wrangel Island. We wish to express our appreciation to numerous local residents and industry personnel whose observations added to the data in this report. Logistical support and (or) data were provided by the U.S. Fish and Wildlife Service, the U.S. Bureau of Land Management, the U.S. Bureau of Ocean Energy Management, BP Exploration - Alaska, ConocoPhillips Alaska, ExxonMobil, Caelus Energy Alaska, Hilcorp Alaska, LLC, Eni Petroleum Co. Inc., Polar Bears International, the University of Wyoming (National Science Foundation grant OPP 0732713 ), and prior to 1973, the State of Alaska. We appreciate the constructive suggestions by Layne Adams (USGS), Craig Perham (U.S. Bureau of Ocean Energy Management), and Richard Shideler (Alaska Department of Fish and Game) on earlier versions of this data report.

\section{References Cited}

Adams, A.L., Dickinson, K.J.M., Robertson, B.C., and van Heezik, Y., 2013, An evaluation of the accuracy and performance of lightweight GPS collars in a suburban environment: PLoS One, v. 8, no. 7, https://doi.org/10.1371/ journal.pone.0068496.

Amstrup, S.C., and Gardner, C., 1994, Polar bear maternity denning in the Beaufort Sea: The Journal of Wildlife Management, v. 58, no. 1, p. 1-10.

Amstrup, S.C., McDonald, T.L., and Stirling, I., 2001, Polar bears in the Beaufort Sea-A 30-year mark-recapture case history: Journal of Agricultural, Biological, and Environmental Statistics, v. 6, no. 2, p. 221-234.
Amstrup, S.C., Stirling, I., and Lentfer, J.W., 1986, Past and present status of polar bears in Alaska: Wildlife Society Bulletin, v. 14, no. 3, p. 241-254.

Amstrup, S.C., York, G., McDonald, T.L., Nielson, R., and Simac, K., 2004, Detecting denning polar bears with Forward-Looking Infrared (FLIR) imagery: Bioscience, v. 54 , no. 4 , p. $337-344$.

Bromaghin, J.F., McDonald, T.L., Stirling, I., Derocher, A.E., Richardson, E.S., Regehr, E.V., Douglas, D.C., Durner, G.M., Atwood, T.A., and Amstrup, S.C., 2015, Polar bear population dynamics in the southern Beaufort Sea during a period of sea ice decline: Ecological Applications, v. 25, no. 3, p. 634-651, https://doi.org/10.1890/14-1129.1.

Douglas, D.C., Weinzieri, R., Davidson, S.C., Kays, R., Wikelski, M., and Bohrer, G., 2012, Moderating Argos location errors in animal tracking data: Methods in Ecology and Evolution, v. 3, p. 999-1007, https://doi.org/10.1111/ j.2041-210X.2012.00245.x.

Durner, G.M., 2010, Catalogue of polar bear (Ursus maritimus) maternal den locations in the Beaufort and Chukchi seas and nearby areas, 1910-2018 (ver. 2.0, January 2020): U.S. Geological Survey data release, https://doi.org/10.5066/P9RPHH50.

Durner, G.M., Amstrup, S.C., and Fischbach, A.S., 2003, Habitat characteristics of polar bear terrestrial maternal den sites in northern Alaska: Arctic, v. 56, no. 1, p. 55-62.

Durner, G.M., Fischbach, A.S., Amstrup, S.C., and Douglas, D.C., 2010, Catalogue of polar bear (Ursus maritimus) maternal den locations in the Beaufort Sea and neighboring regions, Alaska, 1910-2010: U.S. Geological Survey Data Series 568, 14 p., https://doi.org/10.3133/ds568.

Fancy, S.G., Pank, L.F., Douglas, D.C., Curby, C.H., Garner, G.W., Amstrup, S.C., and Regelin, W.L., 1988, Satellite telemetry-A new tool for wildlife research and management: U.S. Fish and Wildlife Service Resource Publication 172, $55 \mathrm{p}$.

Fischbach, A.S., Amstrup, S.C., and Douglas, D.C., 2007, Landward and eastward shift of Alaskan polar bear denning associated with recent sea ice changes: Polar Biology, v. 30, no. 11, p. 1395-1405, https://doi.org/10.1007/s00300-0070300-4.

Garner, G.W., Knick, S.T., and Douglas, D.C., 1990, Seasonal movements of adult female polar bears in the Bering and Chukchi Seas, in Darling, L.M., and Archibald, W.R., eds., Bears-Their biology and management, Proceedings of the 8th International Conference on Bear Research and Management, Victoria, British Columbia, Canada, February 20-25, 1989: Washington, D.C., International Association for Bear Research and Management, p. 219-226. 
Lentfer, J.W., 1975, Polar bear denning on drifting sea ice: Journal of Mammalogy, v. 56, no. 3, p. 716-718.

Lentfer, J.W., and Hensel, R.J., 1980, Alaskan polar bear denning: International Conference on Bear Research and Management, v. 3, p. 101-108.

Lentfer, J.W., Hensel, R.J., Gilbert, J.R., and Sorensen, F.E., 1980, Population characteristics of Alaskan polar bears: International Conference on Bear Research and Management, v. 3, p. 109-115.

Lopez, R., Malardé, J., Royer, F., and Gaspar, P., 2014, Improving Argos Doppler location using multiple-model Kalman filtering: IEEE Transactions on Geoscience and Remote Sensing, v. 52, no. 8, p. 4744-4755.

Messier, F., Taylor, M.K., and Ramsay, M.A., 1994, Denning ecology of polar bears in the Canadian Arctic Archipelago: Journal of Mammalogy, v. 75 , no. 2, p. 420-430. https://doi. org/10.2307/1382563.

Olson, J.W., Rode, K.D., Eggett, D., Smith, T.S., Wilson, R.R., Durner, G.M., Fischbach, A., Atwood, T.C., and Douglas, D.C., 2017, Collar temperature sensor data reveal long-term patterns in southern Beaufort Sea polar bear den distribution on pack ice and land: Marine Ecology Progress Series, v. 564, p. 211-224.
Regehr, E.V., Amstrup, S.C., and Stirling, I., 2006, Polar bear population status in the southern Beaufort Sea: U.S. Geological Survey Open-File Report 2006-1337, 20 p.

Rode, K.D., Olson, J., Eggett, D., Douglas, D.C., Durner, G.M., Atwood, T.C., Regehr, E.V., Wilson, R.R., Smith, T., and St. Martin, M., 2018, Den phenology and reproductive success of polar bears in a changing climate: Journal of Mammalogy, v. 99, p. 16-26, https://doi.org/10.1093/ jmammal/gyx181.

Shideler, R.T., 2014, Comparison of techniques to detect denning polar bears-Federal aid final performance report: Juneau, Alaska Department of Fish and Game, Division of Wildlife Conservation, State Wildlife Grant Project T-16- 3-1.0, $16 \mathrm{p}$.

Wagner, F.H., 1999, Whatever happened to the National Biological Survey?: Bioscience, v. 49, no. 3, p. 219-222. 


\section{Appendix 1. Determination of Spatial Uncertainty}

\section{Positions Determined By Global Positioning Systems (GPS)}

Global Positioning System (GPS) location error was assumed to be less than or equal to 30 meters (m) (Adams and others, 2013). The U.S. Geological Survey (USGS) polar bear research program began using military GPS (that is, Precision Lightweight Global Positioning System Receiver [PLGR], Rockwell Collins, Cedar Rapids, Iowa) receivers in 1995. PLGRs were used in on-ground site visits of historical dens for habitat measurements. Routine use of civilian GPS for recording aircraft flight tracks and den locations began in 1999.

\section{Positions Determined by Argos}

Argos 1-sigma (68-percent) location error estimates after filtering with a plausibility algorithm: Location class quality 3 , less than $(<) 400 \mathrm{~m}$; quality $2,<1,000 \mathrm{~m}$; quality $1,<2,500 \mathrm{~m}$; quality $0,<6,800 \mathrm{~m}$; quality A, $<4,100 \mathrm{~m}$; quality B, $<7,600 \mathrm{~m}$; quality $\mathrm{Z},<4,700 \mathrm{~m}$ (Douglas and others, 2012).

\section{Positions Determined by VHF-Aided or Conventional Aircraft Searches Before GPS (That is, Most Records Prior to 1999) and Positions Reported by Others}

Most den locations in this category were recorded to the nearest minute of latitude and longitude. Hence, we assumed a location error of 0.5 nautical miles (that is, one-half a latitude degree minute), or $926 \mathrm{~m}$. We assumed that the position of reported dens was made with topographical maps. 


\section{Appendix 2. Dens Appearing in Durner and Others (2010) That Are Excluded From This Data Series and Its Associated Data Release}

[DenId: U.S. Geological Survey-assigned den identification number]

\begin{tabular}{cl}
\hline DenID & \multicolumn{1}{c}{ Reason for exclusion } \\
\hline 547 & Data review revealed no compelling evidence that this was a maternal den. \\
625 & Review of Argos data found no locations during den tenure. \\
723 & Data review revealed no compelling evidence that this was a maternal den. \\
855 & Review of Argos data found no locations during den tenure. \\
969 & Data review revealed no compelling evidence that this was a maternal den. \\
973 & Duplicate of DenID 972 (Forward-Looking Infrared discovery). \\
989 & Data review revealed no compelling evidence that this was a maternal den. \\
\hline
\end{tabular}




\section{Appendix 3. Definition of Categorical Data Codes}

\begin{tabular}{|c|c|}
\hline Code & Definition \\
\hline \multicolumn{2}{|r|}{ Data_source } \\
\hline $\mathrm{ADFG}$ & Alaska Department of Fish and Game \\
\hline USGS & U.S. Geological Survey, Alaska Science Center \\
\hline INDUSTRY & Petroleum and related industry personnel \\
\hline LOCAL & Residents of coastal villages and homesteads \\
\hline USFWS & US Fish and Wildlife Service, Marine Mammals Management \\
\hline USFWS-ADFG & FWS and ADFG collaboration \\
\hline \multicolumn{2}{|r|}{ Discovery_method } \\
\hline CONVENTIONAL & Discovered during other USGS, FWS and ADFG polar bear field research efforts \\
\hline FLIR & Discovered with Forward-looking Infrared sensors \\
\hline REPORT & Reported to USGS from other individuals or agencies \\
\hline SATELLITE & Discovered through satellite telemetry \\
\hline VHF_RADIO & Discovered through very high frequency (VHF) telemetry \\
\hline \multicolumn{2}{|r|}{ Confirmation } \\
\hline $\mathrm{C}$ & $\begin{array}{l}\text { Denning confirmed by site visit or subsequent observation of female with dependent } \\
\text { young }\end{array}$ \\
\hline $\mathrm{P}$ & $\begin{array}{l}\text { Evidence of denning from satellite-linked tags data but absence of site visit or subse- } \\
\text { quent observation of female with dependent young }\end{array}$ \\
\hline \multicolumn{2}{|r|}{ Substrate } \\
\hline $\mathrm{P}$ & Pack ice - floating and mobile sea ice \\
\hline $\mathrm{F}$ & Fast ice - sea ice attached to land and immobile \\
\hline $\mathrm{L}$ & Land \\
\hline $\mathrm{U}$ & Unknown substrate \\
\hline \multicolumn{2}{|r|}{ Position_method } \\
\hline map & Position assumed to have been estimated with a topographic map \\
\hline aircraft & $\begin{array}{l}\text { Position estimated with aircraft navigation systems (non-Global Positioning System } \\
\text { [GPS]) }\end{array}$ \\
\hline Argos $\mathrm{LC}=$ & $\begin{array}{l}\text { Position estimated from an Argos-radio tag attached to the polar bear, where } \mathrm{LC}=3,2,1 \text {, } \\
0, \mathrm{~A}, \mathrm{~B} \text {, or } \mathrm{Z}\end{array}$ \\
\hline field gps & Position estimated by GPS on site (field, including aircraft) \\
\hline satellite gps & Position estimated by GPS-equipped satellite-radio tag attached to the polar bear \\
\hline
\end{tabular}


Publishing support provided by the U.S. Geological Survey Science Publishing Network, Tacoma Publishing Service Center

For more information concerning the research in this report, contact the Director, Alaska Science Center

U.S. Geological Survey

4210 University Drive

Anchorage, Alaska 99508

https://www.usgs.gov/centers/asc/ 

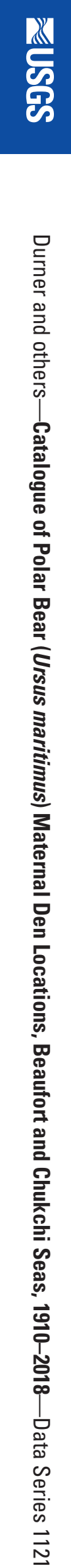